\title{
NATURAL THERAPEUTICS OF MEDICINE IN ISLAM
}

\author{
by Zeyd Ahmad Ali, M.D., Sadiq H. Hussain, D.N. and Ahmad H. Sakr. Ph.D.
}

I. Dr. Zeyd A. Ali, Pathologist at Northwest Memorial Hospital, Chicago, lllinois.

2. Dr. Sadiq H. Hussain, A practitioner at Amman. Jordan.

3. Ahmad H. Sakr, Ph.D., Prof. of Nutritional Biochenistry.

TABLE OF CONTENTS

\section{INTRODUCTION}

II. ISLAMIC VIEWS ON THERAPEUTICS

1II. LIMITATIONS OF DRUG THERAPY

IV. TYPES OF NATURAL THERAPEUTICS

V. ROLE OF DIET IN NATURAL THERAPEUTICS

VI. COLLEGES FOR NATURAL.

1 HERAPEUTICS

A. Definitions

B. Types of Colleges

VII. RECOMMENDATIONS ON NATURAL FOODS

VIII. RECOMMENDATIONS TO THE MUSLIM WORLD

IX. OATH OF A MUSLIM PHYSICIAN

X. SUMMARY

XI. APPENDICES

A. Colleges for Natural Therapeutics

1. Chiropractics

2. Naturopathy

3. Naprapathy

XII. BIBL.IOGRAPHY

\section{INTRODUCTION}

Medicine is both an art and a science. It encompasses prophylaxis or prevention. diagnosis. and finally treatment (both curative and palliative).

Preventive medicine is expecially important and has been neglected as a major factor in health care. In fact, it is well documented but little known that most of the health gains (expressed as life expectancy, morbidity. and mortality) attributed to modern medicine are principally due to advancements in diet and sanitation, rather than to the more complex technologies $, 5,9,10,11$. Preventive medicine as a natural measurc of therapeutic stresses the involvenent of the individual in his own healeh care. This is accomplished by educating the patient as to proper nutrition, hygiene and physical activities $5,10,25$. Equally important are the psychologic and spiritual factors as these can grcally influence the discase 18 .

Curative medicine is as important as the preventive one. In the process of healing. natural approaches have been used. The natural art of therapeutics is not a new approach in the field of medicine. rather it is as old as people have been the inhabitants of this planet. Man has done his best in protecting himself from diseases and in preventing himself from sickness.

Preventive and curative approaches have been used by man to keep himself healthy, happy and strong. Some of these so-called "primitive" measures have been shown to be scientifically sound and have thus been added to the "modern" therapcutic regimens. Some approaches were considered to be natural (e.g. herbs. natural foods, etc.) while others were oriented towards the use of drugs and synthetic remedies.

Anyone studying or practicing medicine realizes that he is at best providing some therapy to impede the disease process so that the body can take over and effect a cure with the mercy of Allah. In an Islamic sense, the health care practitioner must be viewed as an agent through which Allah acts. He must not delude himself into a position of exaggerated self-importance.

In this paper the authors wish to approach the subject of natural therapeutics in medicine vis-a-vis the Islamic approach of good and sound health. The paper will also include some aspects of the following: types of natural therapeutics, diet as an approach to natural healing and colleges that deal with natural therapeutics. The paper does include some recommendations related to natural approaches in medicine for the Muslim world.

Such a paper is helptul to all those concerned about sound health of the individuals including those groups dealing with the allopathic and the natural medicine. This research is of great help to all those colleges teaching medicine and especially those colleges teaching natural therapeutics. It is a source of help to the physicians. patients. hospitals, grocery stores. health food stores and the like. This paper is of great assistance to the Third World, i.e., the emerging nations whose technological resources are meager. and whose health delivery approaches are more or less still oriented towards the nat ural therapcutic methods.

It is the hope of the authors that an eclectic approach be adopted by the Third World, i.e. to pick up the best of every discipline. It is hoped that the Third World nations will establish an INSTITUTE OF HEAL.TH CARE DELIVERY which will calalog the entire spectrum of medical approaches including the "natural" methods. If the Third World nations establish such a health institute based on the natural approaches. they will undoubtedly help save 
themselves money, time, effort and the more expensive technology. This will lead to better healing and finally faster and better results.

\section{ISLAMIC VIEWS ON THERAPEUTICS}

Islam is a way of life to live, a system to be followed. a code of ethics and a constitution to be applied in the daily life of every person. As such, Islam has many construclive ideas to offer in the fields of health and medicine. In order to find out what Islam teaches. one has to read the Quran and the Hadith. Allah says in the Qur'an in Surah the poets (Ash-Shu'ara) about healing from dimnose.

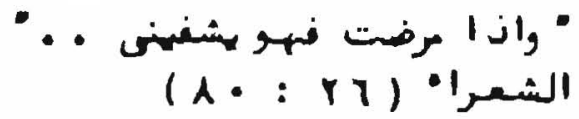

“. . and when 1 sicken, then He (Allah) heals me (26:80)."

As far as the prophet is concerned, related to the healing of diseases, it was reported by Jabir bin Abdullah that prophet Muhammad (pbuh) said:

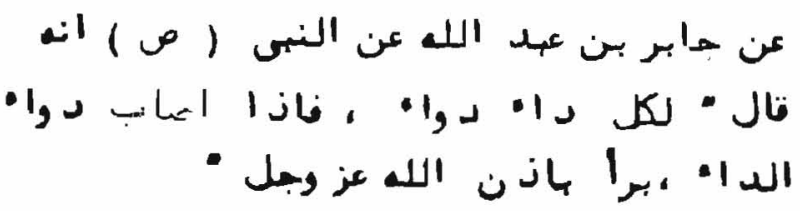

"For any disease there is a cure, and when the cure matches the disease, the person recovers by the will of Allah. .."

The prophet also said about the healing of diseases:
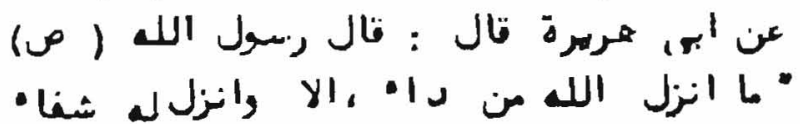

It was reported by Abu Hurairah that the Prophet (pbuh) said:

"Allah never inflices a disease unless he makes a cure for it. .."

As far as the treatment of diseases it was reported by Usamah bin Shareek saying:
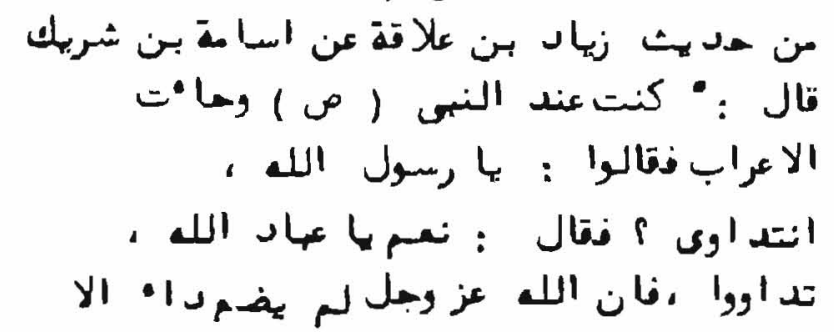

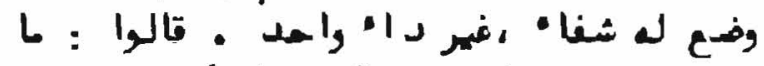

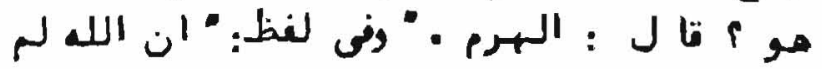
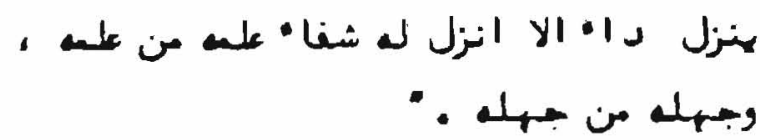

"I was with the Prophet (pbuh) and Arabs came to him asking: ' $O$ messenger of Allah: Do we take medicine for treatment?" He said: 'Yes, Oh you the servants of Allah, take medicine. as Allah Almighty has not created a disease withoul having created a cure for it except one disease. 'They asked, 'What it is?' He said: 'Old age." "In another saying: "Allah never inflicts a disease without providing a cure; only those who were aware of it knew it, whereas those who were not aware, were ignorant of it."

As far as the preventive approach in health. Prophet Muhammad (pbuh) said:

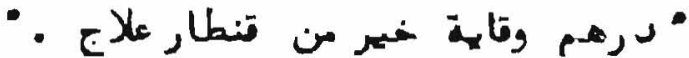

"An ounce or prevention is belter than a ton of treatment."

Hence, healing medicine is an art and a science. It is done through prevention (prophylaxis). diagnosis. treatment. and cure. In so doing. the individua! may prolong his happy life and reduce the degree and the rate of occurrence of illness. Islam encompasses all these approaches so that a person may stay healthy. happy and strong.

\section{LIMITATIONS OF DRUG THERAPY}

Drug therapy has become the concern of many people ${ }^{2}, 22$. The reasons are obvious, among which are the following:

A. Most drug therapy must be closely monitored and carefully dosed. This dose may have to be altered frequently due to the nature of the particular disease process or other concomitant ones the patient may have.

B. Even so, toxic effects may occur. Often one has to weigh the advantages of drug use against the side effects. The choice is not always clcar.

C. Therapeutic drugs are usually much more expensive than preventative measures.

D. The choice whether or not to use drug prescriptions depends greatly on the disease process. Acute, life-1hreatening diseases usually require such intervention. However, for chronic, non-curable diseases (such as arthritis) the rationale for drug prescriptions is much more subjective. The psychologic makeup of the patient is likely to play a large role in the decision to use a drug ${ }^{4},{ }^{623}$.

\section{TYPES OF NATURAL THERAPEUTICS}

Among the natural healing treatments are the following:
A. Preventive medicine
B. Dictetic approach
C. Folk medicine
D. Hakim's medicine 

E. Chiropractic
F. Naturopathy
G. Naprapathy
H. Homeopathy

In dealing with this subject. Islam's approach to healing is an eclectic one, i.e., onc is to use the best of every discipline so that the health of the individual will be preserved.

\section{DIET AND NATURAL HEALING}

As far as the diet is concerned, Islam has laid down the foundation in the Quran and the Sunnah for the best approach in keeping good health. This approach is mainly through selection of the best. preventive methods, and to be aware of any harmful drugs. The following is a summary of the principal ideas of Islam relating to diet and health:

A. Allah asked everyone to eat what is lawful (Halaal). The Qur'an states in Surah Al-Baqarah (the cow):

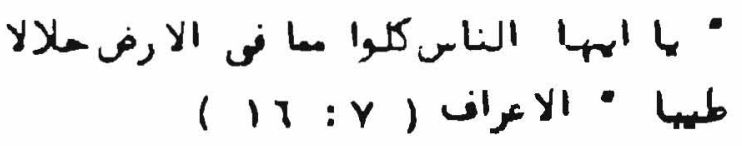

"Ye people: eat of what is on earth, lawful and wholesome" (2:168). Read also (5:91).

B. People are to ENJOY theirfood as it affects their personality character. Enjoying the eating of food is a matter of worship as any other aspect of life in Islam.

C. Muslims are to SELECT the best quality of food. In ths regard Allah says in the Qur'an in Surah Al-Kahf (The Cave):
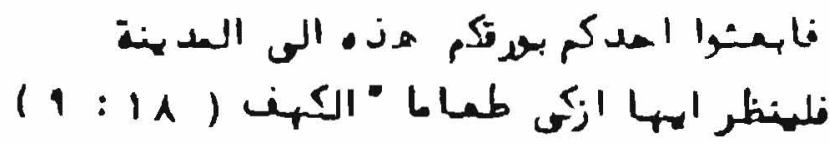

"Now send ye then one of you with this money of yours to the town: let him find out which is the best food (to be had). . " (18:19).

D. Muslims are to EAT the best food after selecting the bcst. Allah says in the Qur'an in Surah AlA'ral (The Heights)

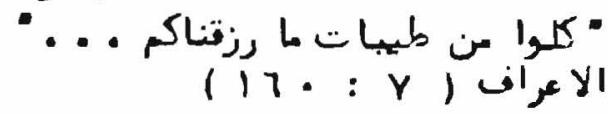

"Eat of the good foods we have provided for you." (7:160).

E. The best approach in the process of prevention is the concept of MODERATION in eating habits. The Quran states emphatically this idea in Surah Al-A raf (The Heights)

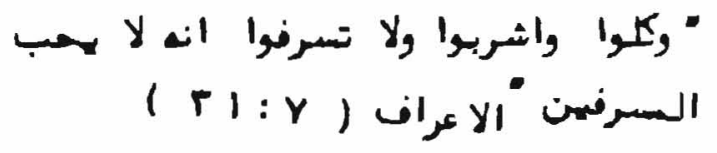

"Eat and drink, but waste not by cxcess, for God loves not the prodigals." (7:31).

F. Regarding the idea of moderation through diet it is mentioned in Surah Taha whereby Allah says:

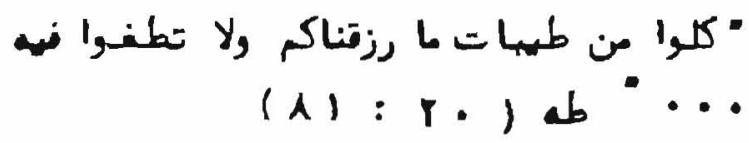

"Eat of the good things we have provided for your sustenance, but commit no excess therein." (20:81)

G. Another approach that Islam demands from its followers is the idea of TOTAL ABSTINENCE of food and drinks for one whole month from dawn to sunset. The benefits of fasting have been tested and documented ${ }^{2},{ }^{2}, 15,16.17$ especially in biochemistry, physiology. clinical therapeutics. clinical nutrition. etc. $l t$ is beyond doubt that fasting helps the individual to get rid of most of the toxins in his body. At the same time fasting increases productivity and by its frugality curbs inflation. In this regard. it would be a good idea to point out here what Islam says in this regard. Allah says in the Qur'an in Surah Al-Baqarah (The Cow):

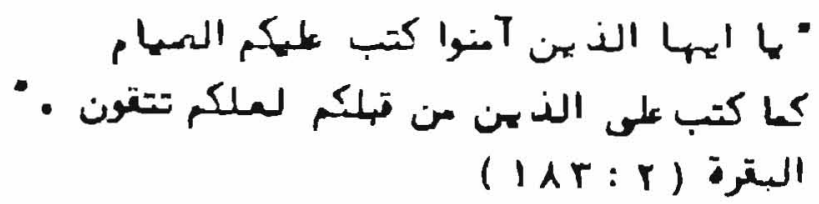

"O ye who telicve! Fasting is prescribed for you as it was prescribed for those before you, that ye may learn self-restraint" i.e. to have Taqua (2:183).

The Prophet Muhammad (pbuh) said:

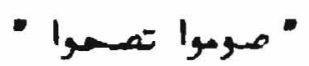

"Fast (the month of Ramadan) so that to heal your bodics from diseases."

The word Taqwa has been explained in many aspects some of which are related to health and disease, food and dictetics, physical fitness, etc. Finally, it has been cxplained to mean: self-training. self-restraint, self-control, self-discipline. selfeducation and self-evaluation.

It should also be mentioned here that the personality, behavior, and performance of the individual is affected by the food eate $n^{k}$ and. therefore, one has 10 select the best type of food for his good health. There is thus a linkage between physical and mental health. A proverb related to this subject has been narrated saying: 
"A sound mind is a sound body and vice versa."

It is difficult to reason well while one is physically sick. Similarly, mentai illness may adversely affect various body functions (e.g. ulcer) 1 . 19. This dual. complementary approach to mental and physical health is exemplified by lslamic views towards the nursing of infants. The advantages of breast fecding are numerous since the mother transfers many nutrients. hormones, and even antibodies through sucklins's. The particular amino acid composition of human milk may accelerate and even increase cognitive development in the infant 's. In addition, one must not forget how this close physical contact strengthens the emotional relationship between the mother and child 13. 14. In this regard. Allah says in the Quran about brcast leeding:

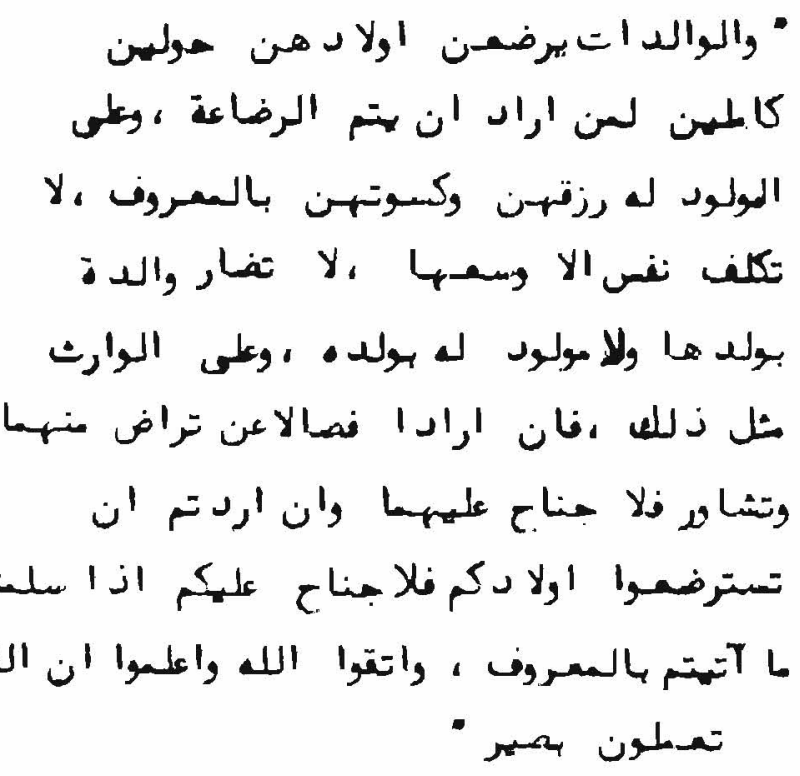

"The mothers shall give suck to their offspring for two whole years if the father desires 10 complcte the term. But he shall bear the cost of their food and clothing on equitable terms. No soul shall have a burden laid on il greater than it can bear. No mother shall be treated unfairly on account of her child, norfathes on account of his child. An heir shall be chargeable in the same way. If they both decide on weaning. by mutual consent, and after due consultation, there is no blame on them. If ye decide on a foster mother for your offspring. there is no blame on you. provided ye pay (the mother) what ye offered, on equitable terms. But fear God and know that God sees well what ye do." $(2: 233)$

\section{COLLEGES FOR NATURAI. THERAPEUTICS}
A. Delinitions
I. Allopathy

"Substituitive therapy" auxotherapy; a therapeutic system in which disease is treated by producing a norbid reaction of another kind or in another part - a method of substitution. "21

\section{Naturopathy}

"A system of therapeutics in which neither surgical nor medical agents are used, dependence being placed only on natural forces. "21

\section{Naprapathy}

a. "A system of therapeutic manipulation based on the theory that morbid symptonts are dependene upon strained or coneracted ligaments in the spine, thorax. or pelvis. " $" 21$

b. From Naprapathic Philosoplyy Notes, Theory and Principles 20 A system of specific manipulative therapeutics based on the theory of interference to nerves, blood vessels and lymph channels, by pathologic soft tissue such as connecrive tissue or muscles with consequent secondary pathology or dysfunction resulting therefrom."

\section{Chiropractic}

"A philosophic system of mechanical therapeutics that attribute discase to vertebral subluxations: it treats discase with manipulation of the vertebra in order to relieve pressure on the nerves at the intervertebral formation so that nerve force may flow freely from the brain to the rest of the body."

\section{Homeopathy}

"A system of therapy developed by Samue! Hahnemann on the theory that large doses of certain drugs given to healthy persons will produce certain conditions which, when occuring spontaneously as symptoms of a disease. are relieved by the same drug in small doses." ${ }^{1} 1$

\section{Osteopathy}

"A school of medicine based upon the idea that the normal body when in "corred adjustment" is a vital machinc capable of making its own remedies against infections and other toxic conditions. Practitioners use the diagnostic and therapeutic measures of ordinary medicine in addition to manipulative measures. "2u!

\section{Folk Medicine}

"Treatment of ailments in the home by remedies and simple measures based upon experiencc and knowledge handed on from generation 10 generation. 21

\section{Acupuncture}

"An ancient medical systen of therapy using puncture by fine needles. Most recently, this has been used for anesthesia." 21 


\section{Preventive Medicine}

"The branch of medical science that treats by the prevention of discase. " 21

\section{Curalive Medicine}

A special type of medicine which is designed to the restoration of health - it means: "to heal, to make well, and is a special method or course of treatment.'2!

\section{Podiatry}

Medical treatment, the specialty that includes the diagnosis and/or medical, surgical, mechanical, physical, and adjunctive treatment of the disease. injuries and defects of the human foot.21

\section{Hakim}

Hakim is an Arabic word. Literally, it means: a wise and a knowledgeable person. In practice it is meant a physician without a formal education or a degree. His knowledge is through personal tutoring as well as through inheritance. The "medicine" that a Hakim practices is composed of a combination of herbal medicine, homeopathy, naturopathy, chiropractic and others. This type of "medicine" is still practiced in most of the "Developing Nations".

\section{B. Types of Colleges}

There are many colleges and institutes in North America dealing with natural healing. Among which are the following:

I. Naturopathic Medicine College

2. Chiropractic Colleges (eighteen colleges in North America).

3. Naprapathy College

4. Homeopathy College

C. General Information

The General Information including the course of study for these colleges of natural therapeutics are found at the end of this article in the Appendices.

\section{RECOMMENDATIONS ON NATURAL FOODS}

\section{A. Natural Foods}

There are four different types of vitamins sold as "natural." These are:

1. An extract of food concentrated so that the vitamin is in higher quantity than the original food - examples: Heart muscle as a source of $B$ vitamins. liver and yeast as sources of B vitamins, rose hips and edible organ meats as sources of vitamin $C$.

2. Highly concentrated crystals or purified vitamins altered somewhat, but extracted from foods - examples: Vitamin E acetate from vegetable oils. from B-12 as cobalamin concentrate.

3. Synthetic vitamins for which the starting materials are natural material - examples: Ascorbic acid from corn sugar, Vitamin A from citral, derived from lemon grass.

4. If a natural base such as yeast is included, the addition of synthetic vitamins may not prevent the product from being called "natural." Many food supplements include ground up deposits of rock from the desert as sources of minerals and these are called "natural" minerals becasue they come from natural rock deposits.

\section{B. Reading Labels}

When reading labels, one has to be careful for the following:

1. Look for Dictary Balance

a. Are the vitamins present in proportion to their individual recommended daily intakes?

b. Do B-complex formulas include all the B-complex vitamins, and are they adjusted to recommended amounts?

c. Are ingredients listed in amounts of active components?

d. Are insignificant amounts of vitamins included for advertising purposes?

e. How much "window dressing" is used"?

f. Are ingredients adjusted to "cost" rather than requirements?

2. Know your preferences for sources

3. Look for expiration dates

4. How well are they assimilated"?

5. Know what you mean by "natural" "organic"

a. All vitamms are organic molecules and fall into this chemical classification.

\section{RECOMMENDATIONS TO THE MUSLIM WORLD}

It is recommended that the Muslim World look into the concept. philosophy and benefits of the natural and practical implications. $I t$ is also recommended that the ministries of public health in cooperation with the ministries of higher education should establish colleges of natural healing arts. Such colleges should include all types of natural healing including the old Arab Hakim, folk medicine. homeopathy, naturopathy, chiropractic, naprapathy and the like. It is recommended that they take into consideration an eclectic approach as well as the needs of the Muslims everywhere: urban and rural areas. Since most of the people in the Muslim World are inclined to a natural approach of healing. such a project could be very successful, very beneficial, less expensive and much safer to the lives of the individuals. 


\section{OATH OF A MUSLIM PHYSICIAN}

For the first time in the bistory of America, a professional group such as the Istamic Medical Association of the USA and Canada (IMA) adopted a professional oath in 1977. "This oath is known as "The Oath of a Muslim Physician". This oath has been adopted in English and Arabic languages and is used yearly by the members of the IMA in their annual conventions. The followingis the oath in the English language:

"Praise be to Allah (God), the Teacher. the Unique. Majesty of the heavens. the exalted, the glorious. Glory be to Him, the Eternal Being who created the Universe and all the creatures within. and the only Being who containeth the infinity and the eternity. We serve no other god besides Thee and regard idolatry as an abominable injustice.

Give us the strength to be truthful, honest, modest, merciful and objective.

Give us the fortitude to admit our mistakes, to amend our ways and to forgive the wrongs of others.

Give us the wisdom to comfort and counsel all towards peace and harmony.

Give us the understanding that ours is a profession sacred that deals with your most precious gifts of life and intellect.

Therefore, make us worthy of this favoured station with honor, dignity and piety so that we may devorc our lives in serving mankind, poor or rich, wise or illiterate, Muslim or non-Muslim, black or white, with patience and tolerance with virtue and reverence. with knowledge and vigilance. with thy love in our hearts and compassion for thy servants. thy most precious creation.

Hereby we take this oath in thy name. the Creator of all the Heavens and the carth and follow thy counsel as thou have revealed to Prophet Muhammad (pbuln).

"Whoever killeth a human being, not in lieu of a nother human being nor because of mischief on earth. as if he hath killed all mankind. And if he saveth a human life. he hath saved the life of all mankind." (Qur'an 5:32)

The following is the Arabic version of the same oath:

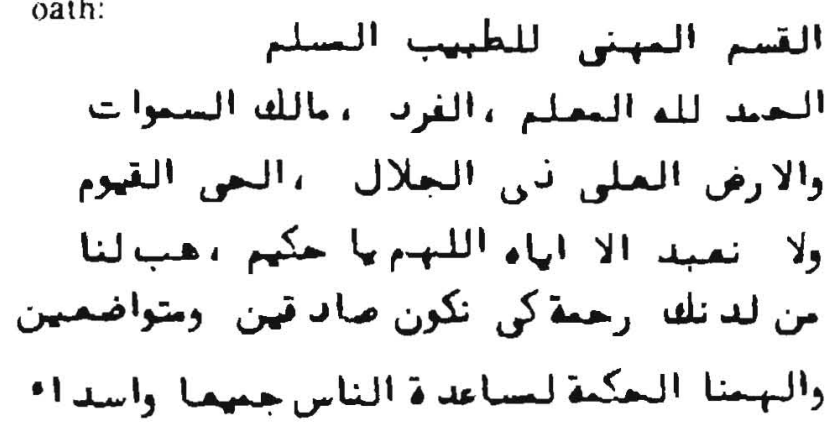

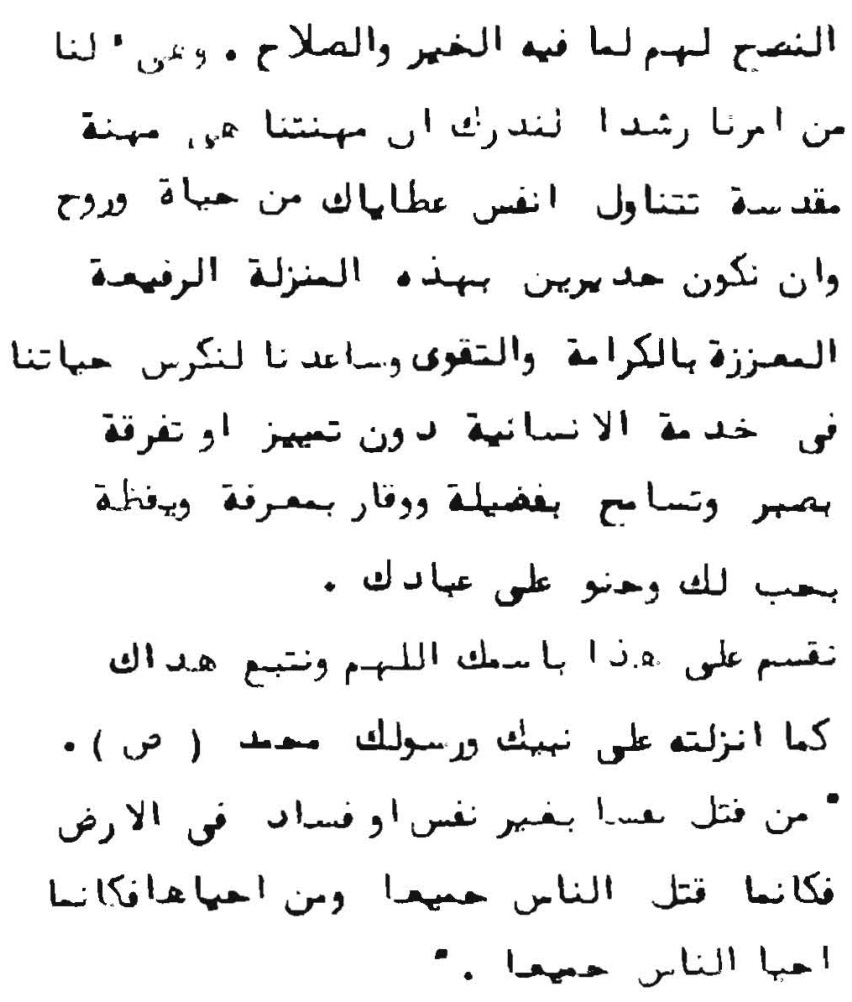

X. SUMMARY

The subject of "Natural Therapeutics" has become important in our daily life. This article has dealt with this subject vis-a-vis the lslamic approach of good and sound health. The paper included types of therapeutics, limitations of drug therapy, colleges dealing with natural therapeutics, recommendations on natural foods, rccommendations of the Muslim World and an "Oath of a Muslim Physician".

One of the important points brought out in this paper is the eclectic approach which should be adopted through the establishment of an institute of health delivery.

\section{APPENDICES}

The following include colleges for natural therapeutics. Some major information about them as well as the courses offered by those colleges. These appendices are important in evaluating the effectiveness of these colleges in training practitioners to handle patients.

\section{APPENDIX ONE: CHIROPRACTIC MEDICINE}

Chiropractic medicine gives particular attention to the relationship of the siructural and neurological aspects of the body in health and disease. Its therapeutics utilize adjustive and manipulative procedures, physiological therapeutics, dietary correction and supplementation, kinesiology and rehabilitative procedures, and other drugless procedures to aid in restoration of anatomical relationships and physiologic capabilitics. 
The study of chiropractic medicine requires four and a half years and includes stuty of both the basic sciences (anatomy. embryology. chemistry. biochemislry. microbiology. psychology. and pathology) as well as clinical medicine, chiropractic manipulation, radiology. nutrition, and acupuncture and direct, supervised clinical experience.

\section{APPENDIX TWO: NATUROPATHIC MEDICINE}

Naturopathic medicine is a distinct system of healing - a philosophy, science, art, and practice which seeks to promote health through education and the rational use of natural agents. As a separate profession, naturopathic medicine incorporates all natural methods of healing. including such things as botanical medicines. homeopathy, nutritional therapy. medical elecuricily, psychology. ano manipulative therapies.

The human body possesses tremendous power to heal itself through mechanisms of homeostasis restoring balance in structure and function and adapting to environmental changes. The naturopathic physician uses those therapeutic substances and techniques which act in harmony with the body's selfhealing processes and avoids treatments which arc designed to counteract or supervene them. Ideally. naturopathic methods are applied as a means of stimulating and enhancing this "healing power of nature."

The study of naturopathy requires four years. The first two years emphasize basic medical sciences and include courses in biochemistry. microbiology. pathology. anatomy (gross and microscopic). physiology, immunology, public health. first aid and emergency medicine. and physical diagnosis. The last two years concentrate on clinical practice and include courses in clinical diagnosis. radiology. pharmacology, psychology. physiotherapy, obstetrics and gynecology, pediatrics, nutrition, biomechanics. manipulative therapy, acupuncture. orthopedies. urology. and dermatology. In addition. clinica! externships give direct experience in the practice of this branch of medicine.

\section{APPENDIX THREE: NAPRAPATHY}

Naprapathy is a system of manually applied movements, both passive and active. designed to bring motion. with consequent release of iension. into abnormally tensed and rigid ligaments. muscles and articulations of the human body. These tissues and structures are normally moveable, flexible and resilient.

Naprapathy contends that a favorable internal environment is essential for growth, development and maintenance of all normal health. Naprapathy's procedures assist the body to maintain this favorable internal environment by releasing points of tension and by the use of rational dietary and hygienic measures.

The study of naprapathy requires three years after two years of undergraduate study. Course work includes anatomy. genetics. chemistry and biochenistry, microbiology. nutrition. physiology. pathology. kinesiology. and botanical studies, and naprapathic physiology and practice. The third year concentrates mainly on clinical practice.

\section{BIBLIOGRAPHY}

I. Aikman. L. "Nalure's Healing Arts: From Folk Medicine to Modern Drugs." Natonal Geographic Society Books. 1977.

2. Benowicz, R.J. "Non-Prescription Drugs and Their Side Eflects." Grossel and Durlap. A. Filmway Co. Publishers N.Y. 1977.

3. Dingle, I.H. "The Ills of Man" Scientilic American. 293: 77-84, Sept. 1973.

4. Dunlop. D.M.D. "Drug Control and the Brivish Health Service." Annals of Int. Medicine 71 (2): 237-244. 1969.

5. Glazier, W. "The Task of Medicine." Scientific American. 228 (4): 14-33, 1973.

6. Goddard, J.L. "The Medical Business." Scientific American. 293: 161-166, Sept. 1973.

7. Goodhart, R.S. and Shils. M.E. “Modern Nutrition in Health and Disease Dietorherapy" Lea and Febiger. Philadelphia. 1974.

8. Green, L.S. (Editor) Malnutrition, Behavior. and Social Behavior, p. 1-288. Academic Press. N.Y... 1977.

9. Lew. E.A. and Seltzer. F. "Color Survival of Generations Since 1840." Milbank Memorial Fund Quarterly, July 1964.

10. McKeonn. T. and Lowe, C.R. "An Introduction to Social Medicine." F.A. Davis Company, p. 118. 1973.

11. McManus, I.C. "Life Expectancy of ltalian Renaissance Artists." Lancet 266-267. 1975.

12. Muhammad, S.D. Al-Tibb Al-Nabawy (Arabic) Dar Al-Hikmah, Beirul, Lebanon.

13. Newton, N. "Battle Between Breast and Botrle." Psychology Today, p. 68-89, July 1972.

14. Newton, N. "Trebly Sensous Woman." Psychology Today. p. 68-73, July 1971.

15. Sakr, A.H. "Dietary Regulations and Food Habits of Muslims." J. Amer. Diet. Assoc. 58: 23. 1971 .

16. Sakr, A.H. "Fasting in Islam." J. Amer. Diet. Assoc. 67: 17-21, 1975.

17. Sakr, A.H. "Overeating and Behavior" The Muslim Scientist and in J. Islamic Med. Assoc.

18. Selye, H. "Stress: lt's a General Adaption Syndrome." Psychology Today, p. 25-56, Sept. 1969. 
19. Selye, H. "The Stress of Life", McGraw Hill Publishing Co.. 1956.

20. Smith, O. "The Connective Tissue Monograph." Chicago College of Naprapathy Publ, Chicago, 1919.

21. Stedman's Medical Dictionary. Illustrated. 23 rd cd. The Williams \& Wilkins Co. Baltimore. Md. 1976.

22. Stern, E.L. "Prescription Drugs and Their Side Effects." Grossel and Dunlap. A. Filmways Co. Publishers N.Y.. 1975.

23. Stolley, P.D.. Becker, M.H., McEvilla, J.D.. Lasagna L.. Gainor M. Sloane. L.M. "Drug Prescribing and Use in an American Community." Annals of Int. Medicine 76 (4): $537-540,1972$.

24. Vaughan. V., James, R.J.. and Nelson, W.E. Editors. "The Advantages of Breast Fceding" in "Nelson's Textbook of Pediatries". I0th Editon, p. 163-4. W. B. Sanders Publishers, Philadelplia. 1975.

25. Williams. R.J. "Nutrition Against Disease." Pitman Publishng Corp. N.Y.. 1971. 